Jurnal Indonesia Sosial Teknologi: p-ISSN: 2723 - 6609

e-ISSN : 2745-5254

Vol. 2, No. 5 Mei 2021

\title{
PENGARUH AKTIVITAS PERDAGANGAN CSB MALL TERHADAP KINERJA JALAN CIPTO MANGUNKUSUMO KORIDOR SMKN 2 - SMUK BPK PENABUR KOTA CIREBON
}

\section{Adil Prayitno dan Anggitia}

Program Studi Teknik Sipil Sekolah Tinggi Teknologi Cirebon

Email: adilprayitno@yahoo.co.id, anggitiabay10@gmail.com

\section{Abstract}

Jalan Cipto Mangunkusumo is an urban road in the city of Cirebon which currently has various roadside land use activities and a high level of activity. The various land use activities certainly attract movement across the Cipto Mangunkusumo road which directly affects the traffic flow conditions on the road and has the potential to create conflict points that impede the flow of traffic movement. This study aims to determine how the current performance of the Cipto Mangunkusumo road section is measured based on the degree of saturation, travel time and level of service (Level of Service). This research on Jalan Cipto Mangunkusumo was conducted to analyze the level of traffic volume density and the effect of side barriers due to CSB Mall trading activities on road performance parameters and road service levels. The highest traffic volume density level during the 3 days of research on Jalan Cipto Mangunkusumo, Cirebon City, was on Wednesday, June 3, 2020 with the total number based on peak hours, namely 4,906 pcu / hour. Meanwhile, the side friction activity during peak hours, namely 886 pcu / hour, is in the high category, $H$ (a commercial area with high road activity). For its own capacity during peak hours, which is 7,635 pcu / hour, it can still be said to be stable because the research was carried out during thepandemic COVID-19 and the implementation of PSBB (Large-Scale Social Restrictions). The degree of saturation during peak hours is 0.68 pcu / hour when an obstacle occurs on Jalan Cipto Mangunkusumo, Cirebon City. The level of road service on Jalan Cipto Mangunkusumo, Cirebon City, during 12 hours of observation in the field, along the observed Cipto Mangunkusumo Road in Cirebon City (Corridor SMKN2 SMUK BPK Penabur), it can be concluded that the level of road service on these roads is close to the value of $D$ and are in category $C$, namely the traffic flow is stable but the speed and motion of the vehicle is controlled.

Keyword: side barriers; road performance; COVID-19 and Road Capacity.

\begin{abstract}
Abstrak
Jalan Cipto Mangunkusumo merupakan jalan perkotaan di Kota Cirebon yang saat ini memiliki aktivitas guna lahan samping jalan yang beragam serta tingkat kesibukan yang tinggi. Aktivitas guna lahan yang beragam tentunya menarik pergerakan melintasi jalan Cipto Mangunkusumo yang secara langsung mempengaruhi kondisi arus llau lintas pada ruas jalan dan berpotensi menimbulkan titik konflik yang menghambat arus pergerakan lalu lintas. Studi ini bertujuan untuk
\end{abstract}


mengetahui bagaimana kinerja ruas jalan Cipto Mangunkusumo saat ini, diukur berdasarkan derajat kejenuhan, waktu tempuh dan tingkat pelayanan (Level of Service). Penelitian pada Ruas Jalan Cipto Mangunkusumo ini dilakukan untuk menganalisis tingkat kepadatan volume arus lalu lintas dan pengaruh hambatan samping akibat aktivitas perdagangan CSB Mall terhadap parameter-parameter kinerja jalan dan tingkat pelayanan jalan. Tingkat kepadatan volume arus lalu lintas tertinggi selama 3 hari penelitian di Ruas Jalan Cipto Mangunkusumo Kota Cirebon, berada pada hari Rabu tanggal 03 Juni 2020 dengan jumlah total keseluruhan berdasarkan pada saat jam puncak yaitu sebesar 4.906 smp/jam. Sedangkan aktivitas hambatan samping pada saat jam puncak yaitu $886 \mathrm{smp} / \mathrm{jam}$ termasuk dalam kategori tinggi, $\mathrm{H}$ (daerah niaga dengan aktivitas jalan yang tinggi). Untuk kapasitas sendiri pada saat jam puncak yaitu $7.635 \mathrm{smp} / \mathrm{jam}$ hal tersebut masih dapat dikatakan stabil karena penelitian dilakukan pada masa pandemic COVID-19 dan penerapan PSBB (Pembatasan Sosial Berskala Besar). Derajat kejenuhan pada saat jam puncak yaitu $0.68 \mathrm{smp} / \mathrm{jam}$ pada saat terjadinya suatu hambatan pada Ruas Jalan Cipto Mangunkusumo Kota Cirebon. Besar tingkat pelayanan jalan pada Ruas Jalan Cipto Mangunkusumo Kota Cirebon, selama 12 jam pengamatan di lapangan, sepanjang Ruas Jalan Cipto Mangunkusumo Kota Cirebon yang diamati (Koridor SMKN2-SMUK BPK Penabur) maka dapat disimpulkan tingkat pelayanan jalan pada ruas jalan tersebut mendekati nilai D dan berada pada kategori $\mathrm{C}$, yaitu arus lalu lintas stabil tetapi kecepatan dan gerak kendaraan dikendalikan.

Kata kunci: hambatan samping; kinerja jalan; COVID-19 dan Kapasitas Jalan.

\section{Pendahuluan}

Perubahan dan perkembangan sistem kegiatan ekonomi dan sosial dipengaruhi salah satunya oleh sistem transportasi. Sistem transportasi menjadi faktor penting yang mempengaruhi kelancaran dan kestabilan prubahan sistem dan ekonomi sosial pada suatu kota tertentu (Kurniawan, 2016). Aktivitas transportasi merupakan arus perpindahan dari suatu kota ke kota lain. Bentuk perpindahan tersebut itu dapat dilihat dari bagaimana tingkat besaran arus lalu lintas di jalan baik melalui arus jalan darat ataupun laut (Kadarisman, Gunawan, \& Ismiyati, 2016). Meningkatnya arus dijalan kota dapat mengakibatkan peningkatan kebutuhan dan ketersediaan sarana prasarana kota (Septiansyah \& Wulansari, 2018). Sistem transportasi kota dapat didefinisikan sebagai satu kesatuan elemen dalam komponen yang saling mendukung terkait pengadaan transportasi yang melayani wilayah perkotaan (Rudi Azis \& Asrul, 2014). Pergerakan menggunakan moda transportasi tidak dapat bergerak jika tidak didukung dengan jaringan transportasi yaitu jalan raya, rel kerata api, bandara, maupun pelabuhan (Sukawati, 2018). Meunurut (Mudaningsih, 2016) upaya pemecahan permasalahan transportasi ini dibutuhkan adanya pembangunan sarana dan prasarana yang dapat mendukung dan mengurangi permasalahan yang ada, terutama menambahkan kapasitas ruas jalan dan manajemen lalu lintas jalan yang terus di tingkatkan. 
Keberadaan perdagangan Cirebon Super Blok (CSB) Mall dapat menimbulkan tarikan (attraction) perjalanan orang maupun kendaraan, dimana keberadaannya harus dibarengi dengan penyediaan sarana seperti penyediaan tempat parkir, fasilitas pejalan kaki, pemberhentian angkutan kota maupun ojek online yang cukup sehingga tidak mengganggu aktivitas pergerakan di jalan. Apabila hal ini tidak mendapat perhatian maka tentu akan menambah beban jalan secara signifikan dan sangat mempengaruhi kinerja jalan itu sendiri, misalnya terjadi kemacetan yang akan mendapat tundaan perjalanan menjadi lebih besar sehingga biaya perjalanan akan menjadi besar pula .

Salah satu kawasan yang selama ini dianggap rawan kemacetan lalu lintas adalah Koridor Jalan Cipto Mangunkusumo Kota Cirebon. Dalam Rencana Tata Ruang Wilayah Kota Cirebon, Jalan Cipto Mangunkusumo termasuk dalam kawasan pendidikan terpadu sehingga aktivitas setiap hari di ruas jalan tersebut meningkat, ditambah lagi dengan banyak aktivitas ekonomi seperti aktivitas perdagangan CSB Mall dan pusat perbelanjaan lainnya, sehingga image kawasan yang multi fungsi menyebabkan kepadatan aktivitas sosial dan ekonomi yang semakin tinggi.

Meskipun bukan satu-satunya penyebab utama penurunan kinerja jalan, terjadinya penambahan volume lalu lintas jalan akan mengakibatkan kemacetan lalu lintas pada ruas jalan disekitar pusat perbelanjaan. Hal ini diakibatkan oleh adanya pergerakan kendaraan keluar masuk CSB Mall dan kendaraan yang menyeberang jalan baik yang bertujuan masuk ke CSB Mall maupun yang bermaksud m2eninggalkan CSB Mall. Keadaan tersebut masih pula diperparah dengan adanya angkutan umum maupun ojek online yang berhenti menunggu penumpang.

Penelitian ini dititik beratkan pada permasalahan mengenai dampak yang ditimbulkan dengan adanya perdagangan Cirebon Super Blok (CSB) Mall terhadap kinerja ruas Jalan Cipto Mangunkusumo Kota Cirebon Koridor SMKN 2 - SMUK BPK PENABUR.

Tujuan penelitian ini adalah (1) Mengetahui dan mempelajari pengaruh aktivitas perdagangan CSB Mall terhadap Kinerja Jalan Cipto Mangunkusumo, (2) Mengetahui hambatan samping yang terjadi di ruas Jalan Cipto Mangunkusumo Koridor SMKN 2 SMUK BPK Penabur. (3) Mengetahui volume lalu lintas, kapasitas jalan dan Tingkat Pelayanan Jalan (Level of Service) akibat pengaruh hambatan samping. (4) Mengetahui V/C Ratio yang terjadi akibat aktivitas perdagangan CSB Mall Kota Cirebon.

Dari hasil penelitian ini penulis berharap dapat memberikan masukan dalam perencanaan pengembangan sistem transportasi di Kota Cirebon dan dapat membantu Pemerintah Kota dalam hal menata arus lalu lintas pada umumnya, sehingga masyarakat dapat menikmati arus lalu lintas yang aman, nyaman dan bebas hambatan.

\section{Metode Penelitian}

\section{Teknik Pengumpulan Data}

Data-data yang digunakan untuk dianalisa didapat dengan cara pengumpulan data primer dan data sekunder sesuai dengan kebutuhan penelitian. Inventarisasi data 
diperoleh dengan melakukan survey langsung dengan instansi terkait. Metode pengumpulan data yang dilakukan adalah sebagai berikut:

\section{Pengumpulan data primer}

Adapun pengumpulan data primer untuk analisis data, terdiri dari:

a. Data Volume Lalu Lintas

b. Data Geometrik Jalan

c. Data Hambatan Samping

d. Data Kapasitas Jalan

e. Data jumlah kendaraan yang keluar masuk CSB Mall

\section{Pengumpulan Data sekunder}

Data tersebut didapatkan dari sejumlah laporan dan dokumen yang telah disusun oleh instansi terkait, serta hasil studi literatur lainya (Indonesia, 1997).

Data yang diperlukan meliputi:

a. Buku Permodelan Transportasi.

b. Buku Manual Kapasitas Jalan Indonesia (MKJI) tahun 1997.

c. Data Jaringan Jalan.

d. Peta Lokasi Penelitian

e. Data jumlah minimal penduduk Kota Cirebon

f. Data Pendukung Lainnya.

\section{Analisis Data}

Metode yang digunakan dalam menganalisa data yang telah dikumpulkan untuk peneltian tersebut adalah dengan Metode Manual Kapasitas Jalan Indonesia (MKJI) tahun 1997.

\section{Hasil dan Pembahasan}

\section{A. Data Geometrik Jalan Cipto}

Kondisi geometrik jalan Cipto Mangunkusumo memiliki alinyemen datar, merupakan jalan empat lajur dua arah terbagi median menggunakan perkerasan asphalt.
1) Status Jalan
: Jalan Perkotaan
2) Bahu Jalan : $40 \mathrm{~cm} / 0,4 \mathrm{~m}$
3) Lebar total tiga Lajur
4) Lajur arah Wahidin : $10.6 \mathrm{~m}$
5) Lebar efektif lajur : $7.6 \mathrm{~m}$
6) Lebar total dua lajur
7) Arah Cipto :9.5 m
8) Lebar efektif lajur : $: 7.4 \mathrm{~m}$
9) Lebar total empat lajur: $20.1 \mathrm{~m}$
10) Lebar perlajur
: $3.4 \mathrm{~m}, 3.6 \mathrm{~m}, 3.6 \mathrm{~m}, 4 \mathrm{~m}$ dan $5.5 \mathrm{~m}$
11) Panjang jalan
: Panjang jalan yang diamati adalah $800 \mathrm{~m}$. 


\section{B. Analisis Hambatan Samping dan Gangguan Pergerakan Lalu Lintas}

Dari pengamatan di lapangan hambatan dan gangguan pergerakan lalu lintas disebabkan banyaknya pejalan kaki yang memenuhi badan jalan, becak yang parkir seenaknya dan banyaknya ojek online yang berhenti di bahu jalan mengingat minimnya lebar bahu jalan. Sehingga pada jam sibuk bercampurnya pejalan kaki dan transportasi lainnya di ruas jalan tersebut mengakibatkan terjadi kemacetan.

Keberadaan aktivitas di kawasan pusat perbelanjaan dan studi seperti perkantoran dan pendidikan sangat mempengaruhi kelancaran pengguna jalan, sehingga memicu peningkatan angka kecelakaan di ruas Jalan Cipto Mangunkusumo. Hambatan samping yang terutama berpengaruh pada kinerja jalan perkotaan sesuai MKJI 1997, adalah:

1) Pejalan Kaki (koefisien $=0,5$ )

2) Angkutan umum dan kendaraan lain berhenti (koefisien $=1,0$ )

3) Kendaraan lambat missal becak, sepeda, kereta kuda ( koefisien $=0,4$ )

4) Kendaraan masuk dan keluar dari lahan di samping jalan (koefisien $=0,7$ )

5) Dari hasil Traffic Counting didapat pada Tabel sebagai berikut:

Tabel 1. Perhitungan Hambatan Samping

Hambatan Kejadian Koefisien Jumlah
Samping

\begin{tabular}{lccc}
\hline $\begin{array}{l}\text { Pejalan } \\
\text { Kaki }\end{array}$ & 376 & 0.50 & 188 \\
\hline $\begin{array}{l}\text { Kend. } \\
\begin{array}{l}\text { Umum/lain } \\
\text { berhenti }\end{array}\end{array}$ & 16 & 1.00 & 16 \\
\hline $\begin{array}{l}\text { Kend. } \\
\text { Masuk dan } \\
\text { Keluar }\end{array}$ & 858 & 0.70 & 600.6 \\
\hline $\begin{array}{l}\text { Kend. } \\
\text { Lambat }\end{array}$ & 203 & 0.40 & 81.2 \\
\hline & Jumlah & $\mathbf{8 8 5 . 8}$ \\
\hline
\end{tabular}

Sumber: Hasil Observasi Lapangan (2020)

Berdasarkan data tabel 1, menunjukkan bahwa jumlah berbobot kejadian per $200 \mathrm{~m}$ per jam pada jam puncak adalah 885,8 diantara 500 - 899 jadi kelas hambatan dikategorikan tinggi dengan bahu jalan $\leq 0.5 \mathrm{~m}$.

Tingkatan hambatan samping membuat ruas jalan yang digunakan menjadi tidak maksimal. Hambatan samping tertinggi yang berada di sepanjang ruas jalan Cipto Mangunkusumo terjadi di titik-titik tertentu yang melewati beberapa kawasan pusat perbelanjaan seperti CSB Mall, Transmart, kawasan perekonomian, perkantoran dan sekolah. Pada ruas jalan Cipto Mangunkusumo khususnya di titiktitik CSB Mall memang memiliki tingkat hambatan samping yang cukup tinggi sehingga kita harus memiliki solusi sebagai peningkatan kinerja lalu lintas di daerah tersebut. Hambatan samping yang banyak terjadi berikutnya adalah tipe parkir, 
berhenti dan pejalan kaki, hal ini di sebabkan oleh banyaknya aktivitas pusat perbelanjaan, perkantoran dan pendidikan yang terdapat di ruas jalan Cipto Mangunkusumo.

Menurut (Dewanto, 2003) hambatan samping yang banyak terjadi berikutnya adalah tipe parkir, berhenti dan pejalan kaki, hal ini di sebabkan oleh banyaknya aktivitas pusat perbelanjaan, perkantoran dan pendidikan yang terdapat di ruas jalan Cipto Mangunkusumo.

Jam padat atau jam puncak kejadian hambatan samping adalah pagi jam 06.00 - 08.00 WIB, siang jam 11.00 - 13.00 WIB dan sore jam 17.00 - 18.00 WIB. Pada jam tersebut terjadi aktivitas di pagi hari orang-orang berangkat kerja, siang hari waktu istirahat yang memungkinkan orang-orang melakukan perjalanan dan pada sore hari orang-orang pulang kerja.

Dari hasil keselutruhan analisis diketahui bahwa aktivitas perdagangan dan jasa di jalan Cipto Mangunkusumo menyebabkan adanya gangguan pada aktivitas lalu lintas di ruas Jalan Cipto Mangunkusumo. Dari penelitian yang telah dilakukan didapat bahwa aktivitas kegiatan perdagangan dan jasa di ruas Jalan Cipto Mangunkusumo berpengaruh besar terhadap perubahan hambatan samping dan jumlah arus lalu lintas, serta berpengaruh sedang terhadap kinerja ruas jalan.

\section{Akumulasi Parkir}

Akumulasi rata-rata parkir per jam pada ruas jalan Cipto Mangunkusumo Kota Cirebon dapat dilihat pada Tabel 2 dan Gambar 1.

Tabel 2. Akumulasi Rata=rata Per Jam Pada Ruas Jalan Cipto Mangunkusumo Kota Cirebon

\begin{tabular}{ccccc}
\hline No & Waktu & Masuk & Keluar & $\begin{array}{c}\text { Akumulasi } \\
\text { Parkir }\end{array}$ \\
\hline 1 & $\begin{array}{l}06.00 \\
07.00\end{array}$ & 5 & 2 & 3 \\
\hline 2 & $\begin{array}{l}07.00 \\
08.00\end{array}$ & 4 & 3 & 4 \\
\hline 3 & $\begin{array}{l}08.00 \\
09.00\end{array}$ & 9 & 3 & 10 \\
\hline 4 & $\begin{array}{l}09.00 \\
10.00\end{array}$ & 9 & 6 & 13 \\
\hline 5 & $\begin{array}{l}10.00 \\
11.00\end{array}$ & 8 & 6 & 15 \\
\hline 6 & $\begin{array}{l}11.00 \\
12.00\end{array}$ & 9 & 10 & 14 \\
\hline 7 & $\begin{array}{l}12.00 \\
13.00\end{array}$ & 11 & 11 & 14 \\
\hline 8 & $\begin{array}{l}13.00 \\
14.00\end{array}$ & 14 & 6 & 22 \\
\hline 9 & $\begin{array}{l}14.00 \\
15.00\end{array}$ & 11 & 9 & 24 \\
\hline 10 & $\begin{array}{l}15.00 \\
16.00\end{array}$ & 10 & 8 & 26 \\
\hline 11 & 16.00 & 10 & 8 & 28 \\
\hline
\end{tabular}




\begin{tabular}{lllll}
\hline & 17.00 & & & \\
\hline 12 & 17.00 & 11 & 16 & 23 \\
\hline
\end{tabular}

Sumber: Analisis Data (2020)

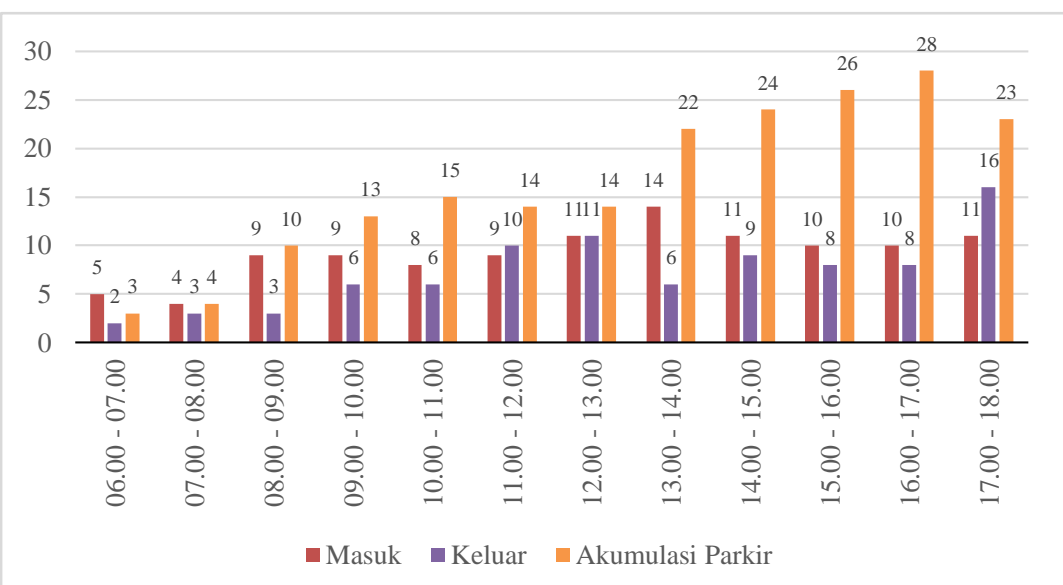

\section{Gambar 1. Fluktuasi Keluar Masuk dan Akumulasi Parkir Jalan Ciptio Mangunkusumo}

\section{Parkir Masuk dan Keluar CSB Mall}

Data hasil survey lapangan pada ruas jalan Cipto Mangunkusumo Kota Cirebon, jalan yang digunakan adalah lajur ketiga pada sisi jalan untuk parkir masuk CSB Mall. Karena pada ruas Jalan Cipto Mangunksuumo akan direncanakan enam lajur maka hanya jalur arah Wahidin (utara) yang baru terealisasikan. Kondisi ini cukup baik untuk mengurangi kemacetan terhadap berkurangnya kapasitas jalan mengingat daerah CSB Mall yang sering mengalami kemacetan akibat pengaruh aktivitas perdagangan CSB Mall Kota Cirebon. Pada jam sibuk lajur ketiga ini sering menyebabkan antrian panjang dan mengakibatkan tundaan dan tentunya kemacetan yang disebabkan olerh kendaraan yang hendak masuk CSB Mall dan mengingat jalan Cipto Mangunkusumo merupakan jalan pusat kota dan akses menuju berbagai jalan perkotaan lainnya, maka kemacetan tak terhindarkan ditambah dengan adanya hambatan samping di sepanjang Ruas Jalan Cipto Mangunkusumo. Untuk lebih jelasnya hasil pengamatan pukul 10.00 WIB (waktu buka CSB Mall) s.d. 18.00 WIB pada hari rabu tanggal 03 Juni 2020 dapat dilihat pada Tabel 3.

Tabel 3. Data Parkir Masuk CSB Mall Kota Cirebon

\begin{tabular}{cccc}
\hline \multirow{2}{*}{ No } & \multirow{2}{*}{ Waktu } & \multicolumn{2}{c}{ Kejadian } \\
\cline { 3 - 4 } & & Mobil & Motor \\
\hline 1 & $10.00-$ & 51 & 54 \\
& 11.00 & & \\
\hline 2 & $11.00-$ & 39 & 56 \\
& 12.00 & & \\
\hline 3 & $12.00-$ & 42 & 68 \\
\hline
\end{tabular}




\begin{tabular}{cccc}
\hline \multicolumn{1}{c}{13.00} & & \\
\hline 4 & $\begin{array}{c}13.00- \\
14.00\end{array}$ & 47 & 43 \\
\hline 5 & $\begin{array}{c}14.00- \\
15.00\end{array}$ & 31 & 56 \\
\hline 6 & $\begin{array}{c}15.00- \\
16.00\end{array}$ & 37 & 45 \\
\hline 7 & $\begin{array}{c}16.00- \\
17.00\end{array}$ & 35 & 66 \\
\hline 8 & $\begin{array}{c}17.00- \\
18.00\end{array}$ & 29 & 72 \\
\hline & Jumlah & $\mathbf{3 1 1}$ & $\mathbf{4 6 9}$
\end{tabular}

Sumber: Analisis Data (2020)

Tabel 4. Data Parkir Keluar CSB Mall Kota Cirebon

\begin{tabular}{|c|c|c|c|}
\hline \multirow{2}{*}{ No } & \multirow{2}{*}{ Waktu } & \multicolumn{2}{|c|}{ Kejadian } \\
\hline & & Mobil & Motor \\
\hline 1 & $\begin{array}{c}10.00- \\
11.00\end{array}$ & 7 & 23 \\
\hline 2 & $\begin{array}{c}11.00- \\
12.00\end{array}$ & 11 & 51 \\
\hline 3 & $\begin{array}{c}12.00- \\
13.00\end{array}$ & 24 & 32 \\
\hline 4 & $\begin{array}{c}13.00- \\
14.00\end{array}$ & 12 & 38 \\
\hline 5 & $\begin{array}{c}14.00- \\
15.00\end{array}$ & 17 & 57 \\
\hline 6 & $\begin{array}{c}15.00- \\
16.00\end{array}$ & 28 & 45 \\
\hline 7 & $\begin{array}{c}16.00- \\
17.00\end{array}$ & 19 & 56 \\
\hline 8 & $\begin{array}{c}17.00- \\
18.00\end{array}$ & 48 & 75 \\
\hline
\end{tabular}

Sumber: Analisis Data (2020)

Berdasarkan dari pengumpulan data karakteristik jalan diatas, dapat dilihat bahwa kondisi lalu lintas dapat dilihat dari fluktuasi volume lalu lintas yang ada. Pengamatan ini dilakukan pada saat pandemi COVID-19 sehingga ada beberapa wilayah yang harus menerapkan sistem pembatasan sosial berskala besar dan menyebabkan manusia tidak melakukan perjalanan selama waktu yang ditentukan.

Hasil pengamatan ini juga membuktikan bahwa pada masa pandemi arus lalu lintas Ruas Jalan Cipto Mangunkusumo Kota Cirebon menjadi lebih stabil, hanya pada jam tertentu saja mengalami kemacetan namun masih dapat dikendalikan oleh para pengendara. 
E. Analisis Perhitungan Ruas Jalan Cipto Mangunkusumo Jalur Wahidin (utara Kota Cirebon)

Tabel 5. Rekapitulasi Hasil Survey Jalan Cipto Mangunkusumo Jalur arah Wahidin (utara) Kota Cirebon

\begin{tabular}{|c|c|c|c|c|c|c|}
\hline \multirow{2}{*}{ Waktu } & \multicolumn{4}{|c|}{ Kendaraan (perjam) } & \multirow{2}{*}{ Jumlah } & \multirow{2}{*}{$\begin{array}{l}\text { Vol. } \\
\text { Maks }\end{array}$} \\
\hline & MC & $\mathbf{L V}$ & HV & UM & & \\
\hline $7 .^{00} 7 .^{15}$ & 531 & 311 & 10 & 14 & 866 & \multirow{5}{*}{3.231} \\
\hline $7 .^{15} 7 .^{30}$ & 477 & 320 & 12 & 7 & 816 & \\
\hline $7 .^{30} 7 .^{45}$ & 547 & 297 & 5 & 3 & 852 & \\
\hline $7 .^{45} 8 .^{00}$ & 438 & 243 & 7 & 9 & 697 & \\
\hline Jumlah & 1993 & $\begin{array}{c}117 \\
1\end{array}$ & 34 & 33 & 3231 & \\
\hline
\end{tabular}

Sumber: Hasil Survey Kendaraan (2020)

Tabel 5. Rekapitulasi Hasil Survey Jalan Cipto Mangunkusumo Jalur arah Wahidin Kota Cirebon

\begin{tabular}{|c|c|c|c|c|c|c|}
\hline \multirow{2}{*}{ Waktu } & \multicolumn{4}{|c|}{ Kendaraan (perjam) } & \multirow{2}{*}{ Jumlah } & \multirow{2}{*}{$\begin{array}{l}\text { Vol. } \\
\text { Maks }\end{array}$} \\
\hline & MC & $\mathbf{L V}$ & HV & UM & & \\
\hline $\begin{array}{l}17 .^{00} \\
17 .^{15}\end{array}$ & 720 & 430 & 13 & 3 & 1166 & \multirow{5}{*}{5.260} \\
\hline $\begin{array}{l}17 .^{15} \\
17 .^{30}\end{array}$ & 832 & 577 & 9 & 4 & 1422 & \\
\hline $\begin{array}{l}17 .^{30} \\
17 . .^{45}\end{array}$ & 774 & 603 & 10 & 3 & 1390 & \\
\hline $\begin{array}{l}17 .^{45} \\
18.00\end{array}$ & 744 & 528 & 8 & 2 & 1282 & \\
\hline Jumlah & 3070 & $\begin{array}{c}213 \\
8\end{array}$ & 40 & 12 & 5260 & \\
\hline
\end{tabular}

Sumber: Hasil Survey Kendaraan (2020)

Keterangan:

a. MC : sesuai dengan MKJI 1007, MC adalah sepeda motor.

b. LV : sesuai dengan MKJI 1997, termasuk mobil penumpang, minibus, pick up, truk kecil, jeep. Pada perhitungan di lapangan, LV adalah angkot, kendaraan pribadi, elf, bus sedang, truk sedang, dan pick up.

c. HV : sesuai dengan MKJI 1997, termasuk truk dan bus. Pada perhitungan di lapangan, HV adalah bus besar, truk besar dan truk gandeng.

Motor (MC)

Kend. Ringan (LV)

Kend. Berat (HV)

Jumlah Kendaraan (Q)
: $3070 \mathrm{Kend} / \mathrm{Jam}$

: $2138 \mathrm{Kend} / \mathrm{jam}$

$: \underline{40 \mathrm{Kend} / \mathrm{Jam}}+$ 


\section{Arus dalam SMP}

Nilai faktor ekivalen smp untuk masing-masing kendaraan:

MC : $0.25 \mathrm{smp}$ (tabel 2.10) untuk jalan terbagi.

LV : $1.00 \mathrm{smp}$ (tabel 2.10) untuk jalan terbagi.

$\mathrm{HV}: 1.20 \mathrm{smp}$ (tabel 2.10) untuk jalan terbagi.

Motor (MC) $\quad: 3070 \times 0.25=768$

Kend. Ringan (LV): $2138 \times 1.00=2.138$

Kend. Berat (HV) : $40 \times 1.20=48$

Jumlah Kendaraan $(\mathrm{Q}) \quad=2.954 \approx \mathbf{2 . 9 5 4} \mathbf{~ s m p} / \mathbf{j a m}$

1) Volume Lalu lintas

$$
\begin{aligned}
& \mathbf{Q}=\frac{\mathbf{N}}{\mathbf{T}} \\
& \mathrm{Q}=2.954 \mathrm{smp} / 1 \mathrm{jam} \\
& =2.954 \mathrm{smp} / \mathrm{jam}
\end{aligned}
$$

$\rightarrow$ Besar volume lalu lintas kendaraan menurut survey yang telah di lakukan pada tanggal 3 Juni 2020 adalah 2.954 smp/jam.

2) Kapasitas

\section{C $=$ Co $\times$ FCw $\times$ FCsp $\times$ FCsf $\times$ FCes}

$\mathrm{C}=4.950 \times 1.00 \times 1.00 \times 0.88 \times 1.00$

$\mathrm{C}=4.356 \mathrm{smp} / \mathrm{jam} \quad=4.356 \mathrm{smp} / \mathrm{jam}$ ( $\mathrm{satu}$ arah $)$.

$\rightarrow$ Kapasitas jalan raya Cipto Mangunkusumo hasil perhitungan sesuai rumus MKJI 1997 adalah sebesar 4.356 smp/jam dan ini volume lalu lintas menurut survey di lapangan yaitu sebesar $2.954 \mathrm{smp} / \mathrm{jam}$, volume lalu lintas belum mendekati kapasitas jalan pada saat pandemi COVID-19 dan dapat dikatakan lalu lintas masih stabil.

3) Kecepatan dan Waktu tempuh

$$
V=\frac{L}{T T}
$$

Rata-rata waktu tempuh $=1$ menit 28 detik

$$
\begin{aligned}
& =0.0245 \text { jam } \\
\mathrm{V} & =0.8 \\
& 0.0245 \mathrm{jam} \\
\mathrm{V} & =33 \mathrm{~km} / \mathrm{jam}
\end{aligned}
$$

$\rightarrow$ Kecepatan kendaraan yang melintas di jalan Cipto Mangunkusumo adalah 33 $\mathrm{km} / \mathrm{jam}$ dengan memakan waktu 1 menit $28 \mathrm{detik} / \mathrm{km}$.

4) Derajat Kejenuhan (DS)

$$
\begin{aligned}
\text { DS }=\frac{\mathbf{Q}}{\mathbf{C}} & \\
\text { DS } & =\frac{2.954 \mathrm{smp} / \mathrm{jam}}{4.356 \mathrm{smp} / \mathrm{jam}} \\
& =0.68 \mathrm{smp} / \mathrm{jam}
\end{aligned}
$$


$\rightarrow$ Derajat Kejenuhan menunjukkan apakah segmen jalan mempunyai masalah kapasitas atau tidak. Derajat kejenuhan jalan raya Cipto Mangunkusumo adalah 0.68. Hal ini akan menentukan tingkat pelayanan jalan (Level of Service).

5) Tingkat Pelayanan Jalan (Level of Service)

Dengan hasil perhitungan derajat kejenuhan jalan raya Cipto Mangunkusumo adalah sebesar 0,68 menunjukkan bahwa tingkat pelayanan jalan raya Cipto Mangunkusumo pada saat pandemi termasuk tipe $\mathrm{C}$ yaitu lalu lintas stabil tetapi kecepatan dan pergerakan kendaraan dikendalikan oleh volume lalu lintas yang lebih tinggi.

F. Analisis Perhitungan Ruas Jalan Cipto Mangunkusumo Jalur Cipto (selatan) Kota Cirebon

Tabel 6. Rekapitulasi Hasil Survey Jalan Cipto Mangunkusumo Jalur arah Cipto (selatan) Kota Cirebon.

\begin{tabular}{|c|c|c|c|c|c|c|}
\hline \multirow{2}{*}{ Waktu } & \multicolumn{4}{|c|}{ Kendaraan (perjam) } & \multirow{2}{*}{ Jumlah } & \multirow{2}{*}{$\begin{array}{l}\text { Vol. } \\
\text { Maks }\end{array}$} \\
\hline & MC & $\mathbf{L V}$ & HV & $\mathbf{U M}$ & & \\
\hline $7 .^{00} 7 . .^{15}$ & 645 & 336 & 5 & 3 & 989 & \multirow{5}{*}{3.834} \\
\hline $7 . .^{15} 7 .^{30}$ & 620 & 357 & 7 & 6 & 990 & \\
\hline $7 .^{30} 7 . .^{45}$ & 613 & 312 & 4 & 9 & 938 & \\
\hline $7 .^{45} 8 .^{00}$ & 597 & 298 & 9 & 13 & 917 & \\
\hline Jumlah & 2475 & 1303 & 25 & 31 & 3834 & \\
\hline
\end{tabular}

Sumber: Hasil Survey Kendaraan (2020)

Tabel 7. Rekapitulasi Hasil Survey Jalan Cipto Mangunkusumo Jalur arah Cipto (selatan) Kota Cirebon

\begin{tabular}{|c|c|c|c|c|c|c|}
\hline \multirow{2}{*}{ Waktu } & \multicolumn{4}{|c|}{ Kendaraan (perjam) } & \multirow{2}{*}{ Jumlah } & \multirow{2}{*}{$\begin{array}{c}\text { Vol. } \\
\text { Maks }\end{array}$} \\
\hline & MC & $\mathbf{L V}$ & HV & UM & & \\
\hline $17 .^{00} 17^{15}$ & 643 & 337 & 7 & 4 & 991 & \\
\hline $17 .^{15} 17 .^{30}$ & 672 & 292 & 9 & 2 & 975 & \\
\hline $17 .^{30} 17 .^{45}$ & 539 & 231 & 4 & 7 & 781 & 3.576 \\
\hline $17 .^{45} 18 .^{00}$ & 574 & 243 & 8 & 4 & 829 & \\
\hline Jumlah & 2428 & 1103 & 28 & 17 & 3576 & \\
\hline
\end{tabular}

Sumber: Hasil Survey Kendaraan (2020)

Motor (MC) : $2475 \mathrm{Kend} / \mathrm{Jam}$ 


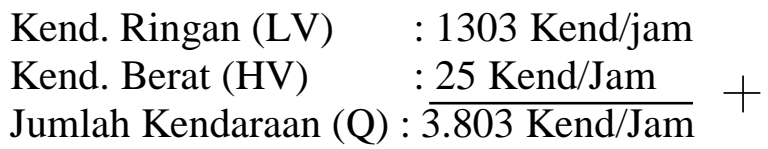

\section{Arus dalam SMP}

Nilai faktor ekivalen smp untuk masing-masing kendaraan:

MC : $0.25 \mathrm{smp}$ (tabel 2.10) untuk jalan terbagi.

LV : $1.00 \mathrm{smp}$ (tabel 2.10) untuk jalan terbagi.

HV : $1.20 \mathrm{smp}$ (tabel 2.10) untuk jalan terbagi.

Motor (MC) $\quad: 2475 \times 0.25=619$

Kend. Ringan (LV) $: 1303 \times 1.00=1.303$

Kend. Berat $(\mathrm{HV}) \quad: 25 \times 1.20=30$

Jumlah Kendaraan $(Q) \quad=1.952 \approx \mathbf{1 . 9 5 2} \mathbf{~ s m p / j a m ~}$

1) Volume Lalu lintas

$$
\begin{aligned}
\mathbf{Q}= & \frac{\mathbf{N}}{\mathbf{T}} \\
\mathbf{Q} & =1.952 \mathrm{smp} / 1 \mathrm{jam} \\
& =1.952 \mathrm{smp} / \mathrm{jam}
\end{aligned}
$$

$\rightarrow$ Besar volume lalu lintas kendaraan menurut survey yang telah di lakukan pada tanggal 3 Juni 2020 adalah 1.952 smp/jam.

2) Kapasitas

$$
\begin{aligned}
\text { C } & =\text { Co } \times \text { FCw x FCsp x FCsf x FCcs } \\
\mathrm{C} & =3.300 \times 1.08 \times 1.00 \times 0.92 \times 1.00 \\
\mathrm{C} & =3.278,88 \mathrm{smp} / \mathrm{jam} \\
& =3.279 \mathrm{smp} / \mathrm{jam} \text { (satu arah). }
\end{aligned}
$$

$\rightarrow$ Kapasitas jalan raya Cipto Mangunkusumo hasil perhitungan sesuai rumus MKJI 1997 adalah sebesar $3.279 \mathrm{smp} / \mathrm{jam}$ dan ini volume lalu lintas menurut survey di lapangan yaitu sebesar $1.952 \mathrm{smp} / \mathrm{jam}$, volume lalu lintas belum mendekati kapasitas jalan pada saat pandemi COVID-19 dan dapat dikatakan lalu lintas masih stabil.

3) Kecepatan dan Waktu tempuh

$V=\frac{L}{T T}$

Rata-rata waktu tempuh $=1$ menit 12 detik

$=0.020 \mathrm{jam}$

$\mathrm{V}=\frac{0.8}{0.020 \mathrm{jam}}$

$\mathrm{V}=40 \mathrm{~km} / \mathrm{jam}$

$\rightarrow$ Kecepatan kendaraan yang melintas di jalan Cipto Mangunkusumo adalah $40 \mathrm{~km} / \mathrm{jam}$ dengan memakan waktu 1 menit $12 \mathrm{detik} / \mathrm{km}$. 
4) Derajat Kejenuhan (DS)

$$
\begin{aligned}
& \text { DS }=\frac{\mathbf{Q}}{\mathbf{C}} \\
& \text { DS }=\frac{1.952 \mathrm{smp} / \mathrm{jam}}{3.279 \mathrm{smp} / \mathrm{jam}} \\
&=0.60 \mathrm{smp} / \mathrm{jam}
\end{aligned}
$$

$\rightarrow$ Derajat Kejenuhan menunjukkan apakah segmen jalan mempunyai masalah kapasitas atau tidak. Derajat kejenuhan jalan raya Cipto Mangunkusumo adalah 0.60. Hal ini akan menentukan tingkat pelayanan jalan (Level of Service).

5) Tingkat Pelayanan Jalan (Level of Service)

Dengan hasil perhitungan derajat kejenuhan jalan raya Cipto Mangunkusumo adalah sebesar 0,60 menunjukkan bahwa tingkat pelayanan jalan raya Cipto Mangunkusumo pada saat pandemi termasuk tipe C yaitu lalu lintas stabil tetapi kecepatan dan pergerakan kendaraan dikendalikan oleh volume lalu lintas yang lebih tinggi.

\section{G. Pengaruh Aktivitas Perdagangan CSB Mall Terhadap Kinerja Jalan Cipto Pada Masa Pandemic COVID-19}

Kinerja lalu lintas suatu kawasan sangat berkaitan dengan unjuk kerja ruas jalan pada kawasan tersebut. Sehingga untuk meningkatkan kinerja jalan di ruas Jalan Cipto Mangunkusumo Kota Cirebon yang disebabkan oleh aktivitas perdagangan CSB Mall harus dilakukan melalui manajemen lalu lintas di sepanjang koridor jalan tersebut.

Jalan Cipto Mangunkusumo Kota Cirebon dilakukan melalui manajemen lalu lintas di sepanjang koridor tersebut. Manajemen lalu lintas yang dimaksud pada penelitian ini adalah tindakan dalam manajemen lalu lintas yang dilaksanakan melalui cara-cara alternatif jika terjadi kemacetan dengan melihat kondisi jalan yang tidak mungkin dilebarkan lagi.

\section{a. Kapasitas Jalan Cipto}

Tabel 8. Kapasitas Jalan Cipto

\begin{tabular}{ccc}
\hline Hari & Arah & Kapasitas \\
\hline \multirow{2}{*}{ Rabu } & Selatan - & 4653 smp/jam \\
Pagi & Utara & \\
\cline { 2 - 3 } & Utara - & 3279 smp/jam \\
& Selatan \\
\hline \multirow{2}{*}{ Rabu } & Selatan - & 4356 smp/jam \\
Sore & Utara \\
& Utara - & 3279 smp/jam \\
\cline { 2 - 2 } Sumber: Hasil Analisis (2020)
\end{tabular}


Data di atas menjelaskan bahwa. kapasitas jalan sesuai kondisi dalam menampung kendaraan adalah sejumlah kapasitas akibat hambatan samping dari aktivitas perdagangan CSB Mall masing-masing waktu pada saat masa pandemic COVID-19. Aktivitas perdagangan CSB Mall sangat mempengaruhi pengurangan kapasitas akibat parkir sejumlah ojek online yang akan menuju CSB Mall.

\section{b. Kinerja Ruas Jalan Akibat Aktivitas CSB Mall Pada Saat Pandemic} COVID-19

Kinerja ruas jalan diindikasikan dengan beberapa unsur penentu, yaitu derajat kejenuhan, kecepatan kendaraan ringan, waktu tempuh serta tingkat pelayanan jalan (LoS). Berdasarkan analisis dengan bantuan program kaji maka didapat data kinerja ruas Jalan Cipto Mangunkusumo untuk jumlah volume terbesar pada waktu jam sibuk hari kerja yaitu Rabu pagi dan sore dapat dilihat pada tabel 9 berikut:

Tabel 9. Hasil Perhitungan Kinerja Ruas Jalan

\begin{tabular}{|c|c|c|c|c|c|c|c|}
\hline Hari & Arah & $\begin{array}{c}\text { Volume } \\
\text { (Q) }\end{array}$ & Kapasitas & DS & $\begin{array}{c}\text { Kecepatan } \\
\text { (LV) }\end{array}$ & LoS & $\begin{array}{c}\text { Waktu } \\
\text { Tempuh (sec) }\end{array}$ \\
\hline \multirow{2}{*}{ Rabu Pagi } & S-U & 1710 & 4356 & 0.39 & $57 \mathrm{~km} / \mathrm{jam}$ & B & 50 \\
\hline & U-S & 1952 & 3279 & 0.60 & $40 \mathrm{~km} / \mathrm{jam}$ & $\mathrm{C}$ & 72 \\
\hline \multirow{2}{*}{ Rabu Sore } & $\mathrm{S}-\mathrm{U}$ & 2954 & 4356 & 0.68 & $33 \mathrm{~km} / \mathrm{jam}$ & $\mathrm{C}$ & 88 \\
\hline & U-S & 1744 & 3279 & 0.53 & $44 \mathrm{~km} / \mathrm{jam}$ & $\mathrm{C}$ & 65 \\
\hline
\end{tabular}

Sumber: Hasil Perhitungan (2020)

Keseluruhan hasil analisis kinerja ruas menunjukkan bahwa performa ataupun kinerja ruas jalan Cipto Mangunkusumo berada pada kondisi stabil atau dapat dikatakan berada dalam kondisi baik tetapi pada jam tertrntu terjadi sedikit antrian kendaraan. Tingkat pelayanan pada jam puncak adalah tipe $\mathrm{C}$, dimana hal tersebut menunjukkan arus masih stabil.

Berdasarkan hasil observasi langsung dan pengamatan lapangan, untuk beberapa waktu sibuk terutama pada hari Rabu pagi dan sore terlihat sedikit kemacetan karena hambatan samping akibat aktivitas CSB Mall. Konjesti yang ada terlihat dari adanya antrian kendaraan di segmen jalan. Analisis dari kondisi ini adalah kemacetan atau antrian yang disebabkan oleh adanya hambatan samping dari pengaruh perdagangan CSB Mall baik karena orang menyeberang maupun angkutan umum yang berhenti. Tetapi secara umum setelah melewati titik konflik maka arus kembali normal.

\section{Kesimpulan}

Berdasarkan hasil pengamatan dan analisis pembahasan pada BAB IV, perhitungan kapasitas jalan menggunakan panduan Manual Kapasitas Jalan Indonesia tahun 1997 (MKJI, 1997) untuk menganalisa kinerja jalan Cipto Mangunkusumo Kota Cirebon, penyusun dapat menarik kesimpulan sebagai berikut: 
Pengaruh Aktivitas Perdagangan CSB Mall Terhadap Kinerja Jalan Cipto Mangunkusumo Koridor SMKN 2 - SMUK BPK Penabur Kota Cirebon

1. Survey dilakukan pada masa pandemic COVID-19

2. Aktivitas Perdagangan CSB Mall Kota Cirebon menurun pada masa pandemic, oleh karena itu pengaruh aktivitas terhadap kinerja jalan juga menurun dan Ruas jalan Cipto Mangunkusumo dapat dikatakan stabil. 


\section{Bibliography}

Dewanto, B. (2003). Pengaruh Hambatan Samping Terhadap Kinerja Jalan Merdeka di Depan Terminal Cimone Kota Tangerang. Program Pascasarjana Universitas Diponegoro.

Indonesia, M. K. J. (1997). Departemen Pekerjaan Umum. Direktorat Jenderal Bina Marga.

Kadarisman, M., Gunawan, A., \& Ismiyati, I. (2016). Kebijakan Manajemen Transportasi darat dan dampaknya terhadap perekonomian masyarakat di Kota Depok. Jurnal Manajemen Transportasi \& Logistik, 3(1), 41-58.

Kurniawan, S. (2016). Analisis Hambatan Samping Akibat Aktivitas Perdagangan Modern (Studi Kasus: Pada Jalan Brigjen Katamso di Bandar Lampung). TAPAK (Teknologi Aplikasi Konstruksi): Jurnal Program Studi Teknik Sipil, 5(1).

Mudaningsih, D. A. (2016). Pengaruh Aktivitas Perdagangan dan Jasa Terhadap Kinerja Jalan Rogowongso, Kabupaten Pati. Semarang: Fakultas Teknik UNISSULA.

Rizani, Ahmad, 2013, "Evaluasi Kinerja Jalan Akibat Hambatan Samping", ITB, Bandung.

Rudi Azis, S. T., \& Asrul, S. T. (2014). Pengantar Sistem dan Perencanaan Transportasi. Deepublish.

Septiansyah, M. V. M., \& Wulansari, D. N. (2018). Analisa Kinerja Ruas Jalan Medan Merdeka Barat, DKI Jakarta. Jurnal Kajian Teknik Sipil, 3(2), 110-115.

Sukawati, H. K. (2018). Pengaruh Aktivitas Perdagangan dan Jasa Terhadap Kondisi Lalu Lintas Jalan R. Suprapto Purwodadi. Universitas Islam Sultan Agung. 